\title{
Herpes Zoster Following Covaxin Receipt
}

\author{
Oumer Abdu Muhie (1D \\ Haylemariam Adera' \\ Eyob Tsige' \\ Aschalew Afework $\mathbb{D}^{2}$ \\ 'Department of Internal Medicine, \\ GAMBY Teaching General Hospital, Bahir \\ Dar, Ethiopia; ${ }^{2}$ Department of Public \\ Health, GAMBY Teaching General \\ Hospital, Bahir Dar, Ethiopia
}

Background: Herpes zoster is a reactivation of varicella zoster virus infection. We presented this case since it occurred after the receipt of Covaxin vaccine. There are few case reports of herpes zoster after the receipt of COVID-19 vaccine in the literature.

Case Presentation: We presented a case of herpes zoster in a 72-year-old lady after she received the first dose of the vaccine for COVID-19. She had post-herpetic neuralgia.

Conclusion: It is evident that VZV reactivation is one of the untoward events of the COVID-19 vaccine. However, it is wise to do large epidemiologic studies to check how common herpes zoster is after the receipt of COVID-19 vaccine.

Keywords: herpes zoster, vaccine, COVID-19, Ethiopia

\section{Background}

Coronavirus disease (COVID-19) is a pandemic that affects multiple systems. It may present with a wide spectrum of cutaneous manifestations. Among the cutaneous manifestations: widespread urticarial, erythematous rash, and chicken poxlike lesions are mentioned. ${ }^{1}$ Currently, there are commercially available vaccines that are deployed to prevent COVID-19 disease and viral transmission. There are at least eleven vaccines for COVID-19 disease. ${ }^{2}$

Until June 4, 2021, a total of 272,285 confirmed COVID-19 cases and 4185 deaths due to COVID-19 were reported to WHO in Ethiopia. Regarding vaccination with COVID-19, as of 30 May 2021, a total of 1,813,739 vaccine doses have been administered. ${ }^{3}$ Currently, the COVAXIN and Sino pharm vaccine are available in Ethiopia in limited numbers.

Varicella zoster virus (VZV) will remain latent in the dorsal root or cranial nerve ganglia after initial acquisition. Herpes zoster is caused by the reactivation of VZV. It may occur spontaneously or be triggered by immunosuppression, trauma, stress, or fever.

\section{Case Presentation}

A 72-year-old female lady who was otherwise healthy presented to our outpatient department with a complaint of left lateral chest pain. She received COVAXIN vaccine a month before her presentation. A week after the receipt of the vaccine, she witnessed a rash on the left lateral chest that had not crossed the midline. There was not much pain initially, but subsequently she started to have pain in the same area. She has no known chronic medical disease. She was not taking any medication that could potentially suppress her immunity. She had no trauma to her chest.

Upon physical examination, she was worried about the chest pain, otherwise she was stable. Her BP was $110 / 70 \mathrm{mmHg}$, PR was 86 per minute. Chest examination
Correspondence: Oumer Abdu Muhie Tel +251921638680

Email umerabdu88@gmail.com 


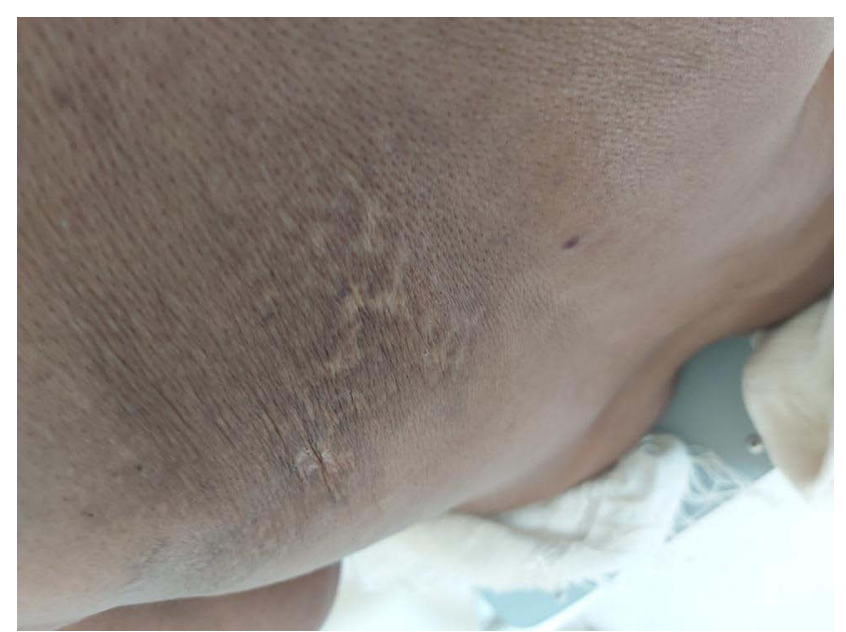

Figure I Healed herpetic scar at T4 dermatome.

was normal. She has a healed herpetic scar on the left T4 dermatome (shown in Figure 1).

During the investigation, we found the fasting blood sugar (FBS) to be $85 \mathrm{mg} / \mathrm{dl}$; her HIV antibody test was nonreactive. Similarly, Rapid Plasma Reagin (RPR, syphilitic test) was negative. Her creatinine was $0.9 \mathrm{mg} / \mathrm{dl}$ and chest radiography was normal.

With the above information, we diagnosed her with herpes zoster with post-herpetic neuralgia.

She was given analgesics and discharged with reassurance.

\section{Discussion}

After the COVID-19 pandemic, VZV reactivation in immunocompetent cases during COVID-19 infection has also been documented, ${ }^{4-6}$ which is believed to develop as a consequence of COVID-19-induced lymphopenia and functional impairment of CD4+ T cells. ${ }^{7,8}$ The median time to development of herpes zoster after COVID-19 diagnosis was reported to be 5.5 days. $^{6}$ In our case, the herpetic rash appeared after seven days of vaccine receipt. There are a couple of case reports mentioning the occurrences of herpes zoster after receipt of COVID-19 vaccine. ${ }^{9-13}$ However, we could not retrieve literatures describing herpes zoster following Covaxin vaccine from PubMed till November 18, 2021.

As mentioned earlier, there were reports of herpes zoster after COVID-19 vaccination. ${ }^{9-13}$ The postulated mechanism predisposing for the reactivation of VZV after vaccination was immunomodulation. ${ }^{14}$ On the other hand, transient lymphopenia following COVID-19 vaccine (similar to VZV reactivation in COVID-19 disease) looks the possible reason for $\mathrm{VZV}$ reactivation after the receipt of the vaccine. ${ }^{9}$ Taking our case and the cases reported by other authors, ${ }^{9-12,15}$ one can draw a link between COVID19 vaccine and reactivation of VZV and thus herpes zoster.

\section{Conclusion}

Generally, the incidence of herpes zoster increases with age. Nevertheless, taking all the case reports about herpes zoster occurrences after receipt of COVID-19 vaccine, it is evident that VZV reactivation is one of the untoward events of the vaccine. However, it is wise to do large epidemiologic studies to check how common herpes zoster is after the receipt of COVID-19 vaccine.

\section{Abbreviations}

COVID-19, Corona Virus disease 19; RPR, Rapid plasma reagin; VZV, varicella zoster virus; WHO, World Health Organization.

\section{Data Sharing Statement}

All important data are included in the manuscript.

\section{Ethics and Consent}

Ethical approval was obtained from GAMBY Medical and Business College review board to publish the case details. Ethics approval and consent to participate: written informed consent was obtained from the case. Written informed consent was obtained from the patient for publication of this case report and any accompanying images.

\section{Author Contributions}

All authors made a significant contribution to the work reported, whether that is in the conception, study design, execution, acquisition of data, analysis and interpretation, or in all these areas; took part in drafting, revising or critically reviewing the article; gave final approval of the version to be published; have agreed on the journal to which the article has been submitted; and agree to be accountable for all aspects of the work.

\section{Funding}

The authors received no financial support for this case report.

\section{Disclosure}

The authors report no conflicts of interest in this work. 


\section{References}

1. Recalcati S. Cutaneous manifestations in COVID-19: a first perspective. J Eur Acad Dermatol Venereol. 2020;34:e212-e213. doi:10.1111/jdv.16387

2. Doroftei B, Ciobica A, Ilie OD, Maftei R, Ilea C. Mini-review discussing the reliability and efficiency of COVID-19 vaccines. Diagnostics. 2021;11(4):579. PMID: 33804914; PMCID: PMC8063839. doi:10.3390/diagnostics 11040579

3. World Health Organization. Ethiopian situation; 2021. Available from: https://covid19.who.int/region/afro/country/et. Accessed June 5, 2021.

4. Ferreira ACAF, Romão TT, Macedo YS, Pupe C, Nascimento OJM. COVID-19 and herpes zoster co-infection presenting with trigeminal neuropathy. Eur $J$ Neurol. 2020;27(9):1748-1750. doi:10.1111/ ene. 14361

5. Saati A, Al-Husayni F, Malibari AA, Bogari AA, Alharbi M. Herpes zoster co-infection in an immunocompetent patient with COVID-19. Cureus. 2020;12(7):e8998. doi:10.7759/cureus.8998

6. Tartari F, Spadotto A, Zengarini C, et al. Herpes zoster in COVID-19positive patients. Int J Dermatol. 2020;59(8):1028-1029. doi:10.1111/ ijd.15001

7. Zheng M, Gao Y, Wang G, et al. Functional exhaustion of antiviral lymphocytes in COVID-19 patients. Cell Mol Immunol. 2020;17 (5):533-535. doi:10.1038/s41423-020-0402-2

8. Cao X. COVID-19: immunopathology and its implications for therapy. Nat Rev Immunol. 2020;20(5):269-270. doi:10.1038/s41577-0200308-3
9. Van Dam CS, Lede I, Schaar J, Al-Dulaimy M, Rösken R, Smits M. Herpes zoster after COVID vaccination. Int $J$ Infect Dis. 2021;111:169-171. PMID: 34428545; PMCID: PMC8379763. doi:10.1016/j.ijid.2021.08.048

10. Iwanaga J, Fukuoka H, Fukuoka N, Yutori H, Ibaragi S, Tubbs RS. A narrative review and clinical anatomy of herpes zoster infection following COVID-19 vaccination. Clin Anat. 2021. PMID: 34554601. doi:10.1002/ca.23790

11. David E, Landriscina A. Herpes zoster following COVID-19 vaccination. J Drugs Dermatol. 2021;20(8):898-900. PMID: 34397201. doi:10.36849/JDD.6146

12. Palanivel JA. Herpes zoster after COVID-19 vaccination-Can the vaccine reactivate latent zoster virus? J Cosmet Dermatol. 2021;20 (11):3376-3377. PMID: 34559453. doi:10.1111/jocd.14470

13. Arora P, Sardana K, Mathachan SR, Malhotra P. Herpes zoster after inactivated COVID-19 vaccine: a cutaneous adverse effect of the vaccine. J Cosmet Dermatol. 2021;20(11):3389-3390. PMID: 34077622; PMCID: PMC8242496. doi:10.1111/jocd.14268

14. Walter R, Hartmann K, Pool V, Gargiullo P, Kuhn M. Reaktivierung von Herpesviren-Infektionen durch Impfungen: evidenz oder Koinzidenz? [Reactivation of herpes virus infections by vaccination: evidence or coincidence?]. Schweiz Med Wochenschr. 2000;130 (44):1685-1688. German. PMID: 11103441.

15. Bostan E, Yalici-Armagan B. Herpes zoster following inactivated COVID-19 vaccine: a coexistence or coincidence? J Cosmet Dermatol. 2021;20:1566-1567. doi:10.1111/jocd.14035
International Medical Case Reports Journal

\section{Publish your work in this journal}

The International Medical Case Reports Journal is an international, peer-reviewed open-access journal publishing original case reports from all medical specialties. Previously unpublished medical posters are also accepted relating to any area of clinical or preclinical science. Submissions should not normally exceed 2,000 words or 4 published pages including figures, diagrams and references. The manuscript management system is completely online and includes a very quick and fair peer-review system, which is all easy to use. Visit http://www.dovepress.com/testimonials.php to read real quotes from published authors. 